\title{
NORMS IN FACE-THREATENING INSTANCES OF SIMULTANEOUS CONFERENCE INTERPRETING: RESULTS FROM A QUESTIONNAIRE
}

\author{
Cédric Lenglet \\ cedric.lenglet@umons.ac.be \\ University of Mons
}

\begin{abstract}
Conference interpreters are expected to act like neutral spokespersons and expert communicators at the same time. To achieve this, they abide by translational norms. These norms can be elicited from the discourse on interpreting, field observation and corpus data. They might also overlap with assessment norms. Anecdotes from the booth and field observations indicate that interpreters sometimes modify the speaker's positions and shape the meaning of the target text. One translational norm could be that face-threatening acts (FTAs) in the source text cause interpreters to deviate from the spokesperson's role and adopt face-saving strategies. This paper explores reactions to FTAs in interpreting through assessment norms. Professional interpreters, interpreting students and academics answered a questionnaire which presented interpreting situations involving an FTA. The respondents had to select the most appropriate reaction(s). No significant inter-group difference was found. A majority of respondents considered deviations from the spokesperson's role to be legitimate in instances of FTAs. This might suggest a link between common face-saving strategies and translational norms in interpreting.
\end{abstract}

\section{Resumen}

Se espera de los intérpretes de conferencia que actúen a la vez como portavoces neutrales y expertos en comunicación. Para ello se ciñen a normas de traducción. Éstas se pueden extraer del discurso sobre la interpretación, de la observación sobre el terreno y de los corpus. Además, estas normas pueden coincidir con las normas de evaluación. Diversas anécdotas y observaciones indican que a veces los intérpretes modifican las posiciones del locutor y el sentido del texto meta. Una norma de traducción podría 
consistir en que los actos amenazantes para la imagen (FTA) del texto original llevan a los intérpretes a desviarse del papel de portavoz y a adoptar estrategias para salvaguardar la imagen. El artículo explora las reacciones ante los FTA en interpretación a través de las normas de evaluación. Varios intérpretes profesionales, estudiantes y académicos completaron un cuestionario que presentaba situaciones de interpretación con un FTA. Tenían que seleccionar la reacción más apropiada. No encontramos una diferencia significativa entre los grupos. La mayoría de los encuestados consideraron que las desviaciones del papel de portavoz son legítimas en casos de FTA. Esto podría indicar la existencia de una relación entre las estrategias comunes para salvaguardar la imagen y las normas de traducción aplicadas a la interpretación.

Keywords: Assessment. Norm. Face-threatening act (FTA). Simultaneous conference interpreting. Questionnaire.

Palabras clave: Evaluación. Norma. Acto amenazante para la imagen (FTA). Interpretación simultánea de conferencia. Cuestionario.

Manuscript received on February 12, 2013 and accepted for publication on December $20,2013$. 


\section{Introduction}

Simultaneous conference interpreters (henceforth, interpreters) are expected to provide a faithful, accurate, lively and clear simultaneous rendition (target text, TT) of a speech uttered in a foreign language (source text, ST) (VV.AA. 1990/2004). Adjectives such as faithful and clear point to "some sort of social consensus as to what is 'right', correct or desirable in interpreting activity" (Pöchhacker \& Shlesinger 2002: 295).

This consensus about 'right or wrong' can be conceptualized as norms (Toury 1980, 1995). Norms can be textual or extra-textual. Textual norms can be elicited by means of an ST and TT comparison, whereas extra-textual norms are found in "explicit normative statements in the literature" (Toury 1980: 57).

In the literature, interpreters are often presented as faithful, impartial and "honest spokespersons" (Harris 1990) who re-express the ST speakers' ideas in the first person. According to Harris (1990: 118), the use of the first person is even a universal norm. At the same time, interpreters are expected to act like expert communicators who are clear and lively in their delivery (VV.AA. 1990/2004). However, reconciling the expert communicator's and the spokesperson's role might cause conflicting situations. For example, what happens if the ST speaker is unclear and monotonous? An expert communicator would probably render a clear and lively TT. But would such an interpretation still be neutral and faithful?

In some cases, extra-textual norms might create a tension between translation-related constraints (adequacy) and target text-related constraints (acceptability). Interpreters do not resolve this tension on an ad hoc basis: they base their choices on translational norms. These norms are manifested by a number of regularities in the interpreting product (Toury 1998: 22), which can be explored by means of corpus-based research on textual norms (i.e. ST/ TT comparison). In this respect, Straniero Sergio \& Falbo (2012) provide a recent overview of emerging works in corpus-based interpreting studies. A different approach consists in asking interpreters to select the best ST/TT correspondence from a list. Their choices hint at norms in the assessment of 
interpreting. These norms do not correspond exactly to translational norms. However, "they can [...] reflect the same overall attitude towards translation" (Toury 1998: 24) and in this case, interpreting.

Previous studies on textual norms have challenged the universality of Harris's universal norm in SI. This paper builds up on results from these studies and adopts an approach based on assessment norms. We compare the attitude of professional interpreters, interpreting students and academics towards deviations from the honest spokesperson's role in SI situations involving a face-threatening act (FTA) (Goffman 1967; Brown \& Levinson 1987). Since norms are acquired by an individual in the process of his or her socialization in an established group (Toury 1998: 17), we hypothesized that assessment norms would vary between professional interpreters, on the one hand, and interpreting student and academics, on the other hand. To check this hypothesis, we conducted a small-scale study, hoping we would enhance the knowledge of norms in SI.

This paper is divided into three parts. Firstly, previous studies, the hypothesis and the explanatory framework of our work are presented. The method and the results of our study are described in the second part of this paper. Thirdly, the results are discussed. We conclude with a few suggestions for future research.

\section{Previous findings and explanatory framework}

In her book De-/Re-Contextualizing Conference Interpreting, Diriker (2004) uses an approach based on Fairclough's Critical Discourse Analysis. She explores the discursive representation of SI as a professional identity. Diriker distinguishes between two types of discourse.

Firstly, professional associations, codes of ethics, handbooks and training institutions often use a decontextualized discourse to describe SI as an abstracted entity. Interpreters are depicted as being able to "identify with the speakers, replace them in the eyes of the audience, and unproblematically access and transfer the original meaning" (Diriker 2004: 48). In the same vein, Harris (1990) mentions a fundamental and universal norm in SI, that of the honest spokesperson, who speaks in the name of the speakers and conveys their message accurately and impartially. The decontextualized discourse also insists on the fluency and on the immediate intelligibility of the interpreters' output (Diriker 2004: 48). In other words, SI appears to be about accurately conveying the ST message while improving the TT package if necessary. This type of enhancement is not considered to contradict any notion of fidelity 
because "such interventions are assumed to take place at the level of the 'word' and not the 'meaning"' (Diriker 2004: 48).

The second type of discourse refers to actual instances of SI and consists mostly of anecdotal accounts told by the interpreters themselves. These anecdotes point to the interpreters' active role in shaping the meaning of the TT. They also suggest that the interpreters' identification with the ST speakers is not as obvious as indicated in the decontextualized discourse (Diriker 2004: 48-49). Diriker also analysed how the interpreters justify their interventions in the TT. Again, they distinguish between meaning and word. They also mention the necessity to sometimes "facilitate the communication" or "bridge cultural differences" (Diriker 2004: 49).

In the second part of her study, Diriker observed interpreters at work during a conference. She found that their use of the speakers' I was not always in line with the honest spokesperson's norm. She observed that the interpreters' "shifts in the speaking subjects" occurred in the following cases:

- the speaker or the interpreter apologize;

- the speaker or the interpreter make a mistake;

- there is confusion in the meeting room and the sound is inaudible;

- sound transmission is poor;

- the ST is ambiguous or incoherent;

- the participants talk about a specific cultural or linguistic issue;

- a speaker uses a language which had not been planned for the meeting;

- a participant accuses the interpreters of making a mistake. (Diriker 2004: 88-115)

In these cases, the interpreters sometimes reported or paraphrased the interaction on the floor (they added "says the speaker"), they "[blended] their remarks into the speaker's 'I" or they "[took] over the speaker-position explicitly by speaking in their own 'I's'" (Diriker 2004: 138).

In conclusion, Diriker's analysis

points to the power of the interpreter in regulating the speaker-positions in the delivery [...] [and] highlights the main negotiator position of the interpreter in working out a discursive representation of the speaker in the delivery. (Diriker 2004: 148)

Monacelli (2009) also observed SI instances which challenge the spokesperson's norm. Monacelli builds up on Diriker's study, where it had been argued that 
the seeming non-presence of the interpreters in the delivery [...] could easily be subverted, leaving all fingers pointing to the interpreters as the culprits of a failed communication. (Diriker 2004: 138)

This leads Monacelli (2009: 23) to characterize interpreting as an inherently face-threatening activity. She analyses the interpreters' behaviour "in terms of self-regulation, i.e. struggle for survival" (Monacelli 2009: 23). She argues that in their quest for professional survival, interpreters "subordinate all activity (linguistic choices, interpersonal professional relations, etc.) to the preservation of their professional 'face"' (2009: 53).

Monacelli's explanatory framework (2009: 79ff.) borrows the concepts of face and face-threatening acts (FTAs) from politeness theory (Goffman 1967, Brown \& Levinson 1987). After Goffman (1967), face is understood in the common sense of saving or losing one's face. Brown \& Levinson (1987) argue that face can be either positive (i.e. a desire that one's projected image be appreciated and positively valued) or negative (i.e. a desire of independence and freedom from imposition). Brown \& Levinson's FTAs are speech acts which threaten the negative or the positive face. These acts can be other-threatening or self-threatening. Brown \& Levinson (1987: 65-68) list a series of intrinsically threatening acts such as orders, requests, promises, compliments (other-threatening, negative face); thanks, acceptance of excuses, unwilling promises (self-threatening, negative face); disapproval, criticism, insults (other-threatening, positive face); apologies, acceptance of a compliment, self-humiliation and confession (self-threatening, positive face).

Speakers tend to cooperate interactively to save their mutual face. Goffman (1967: 12ff.) calls face-saving strategies face-work. Monacelli (2009: 84) lists the following examples of face-work: claiming common ground, seeking cooperation or fulfilling wants (saving positive face), being conventionally indirect and avoiding imposition (saving negative face).

Monacelli (2009) did a qualitative and a quantitative analysis of FTAs and face-work in a corpus of 10 TTs and their STs. She targeted the cases where the ST speakers perform an FTA to ST and TT receivers or to the interpreters (Monacelli 2009: 83). She located the interpreters' face-saving reactions to these FTAs along a continuum composed of three role dimensions (2009: 135ff.).

At one extreme of the continuum, the professional role dimension consists in replaying or relaying the ST. For instance, the interpreters add says the speaker to hold the ST at arm's length. At the other extreme, the personal role dimension covers instances where the interpreters become authors or principals of the TT (see Goffman 1981:144). In such a case, the interpreters' I 
and utterances refer to themselves rather than to the ST speakers. Between the two extremes there is an inter-dimension. In this dimension, the interpreters' I seemingly identifies with the speakers' I as in the spokesperson's role. However, in this inter-dimension, direct observers might perceive the interpreters' utterances as enacted within a personal or a professional role dimension. This is the case when an interpreter self-corrects as in the following TT example: They are accused to be... not to be responsible. Indeed, the text receivers are left with some uncertainty about the origin of such a self-correction, which can be ascribed as much to the ST speaker as to the interpreter (Monacelli 2009: 138-141).

In a second part of her study, Monacelli (2009: 149ff.) organized a debriefing session with her subjects. She showed them two face-threatening situations where the interpreter had departed from the role of an honest spokesperson and asked whether such behaviour was formally taught or professionally acquired. "All subjects answered that the behaviour was acquired from watching senior colleagues on the job" (Monacelli 2009: 152). Like norms, this behaviour had been acquired through socialization.

Monacelli's (2009) findings suggest that interpreters confronted to the ST speaker's FTAs tend to distance themselves from the ST by letting their professional survival prevail over the honest spokesperson's role. The interpreters' face-saving strategies might be characteristic of normative behaviour (Monacelli 2009: 27).

Diriker's (2004) and Monacelli's (2009) observations are based on a manual analysis of interpreting corpora. These corpora are considerable, albeit limited in scope when compared to others (for an overview of recent developments in corpus-based interpreting studies, see Bendazzoli \& Sandrelli 2009, Straniero Sergio \& Falbo 2012). To our best knowledge, there are no studies of the interpreters' reactions to FTAs based on large machine-readable corpora. One explanation might be that pragmatic annotation of large corpora is particularly challenging (Archer et al. 2008).

A different and complementary way of exploring face-saving strategies in SI consists in considering them from the point of view of assessment norms, i.e. norms that do not correspond exactly to translation norms in Toury's (1998) sense, though "they can [...] reflect the same overall attitude towards translation" (or here, interpreting) (Toury 1998: 24). This paper presents a small-scale survey which aims to find whether assessment norms are consistent with the translation norms suggested by Monacelli's (2009) and Diriker's (2004) findings. The study will explore how professional interpreters, interpreting students and academics assess face-saving strategies, and hence 
deviations from the honest spokesperson's role in interpreting. Do they reject or approve these strategies? Additionally, is there a difference between the assessment norms of professional interpreters, on the one hand, and interpreting students and academics, on the other hand? There are some reasons to believe that this should be the case, since previous results imply that face-saving strategies in SI and the attitude towards them might be acquired through professional socialization within the interpreting field.

The following hypothesis is thus formulated: There is a link between the membership to the interpreting profession and the assessment of deviations from the honest spokesperson's role in SI instances containing an FTA.

\section{Method}

\subsection{Subjects}

An on-site survey was organized during a final examination of a Master's degree in SI in a French-speaking interpreting school. Since this is a smallscale study, no sampling was felt to be necessary. Indeed, the aim was not to generalize the findings to a whole population but rather to identify methodological issues and to explore potential trends. The subjects were the examination participants who accepted to take part in the survey.

Data about the subjects are presented in the following table:

Table 1. Subject data

\begin{tabular}{|l|c|c|}
\hline \multicolumn{1}{|c|}{ Subjects } & $\begin{array}{c}\text { Number of } \\
\text { Respondents/Total }\end{array}$ & $\begin{array}{c}\text { Response } \\
\text { Rate }\end{array}$ \\
\hline $\begin{array}{l}\text { Staff interpreters from the external examination } \\
\text { board (i.e. permanent employees of national or } \\
\text { international organizations) }\end{array}$ & $5 / 5$ & $100 \%$ \\
\hline $\begin{array}{l}\text { Interpreter trainers who are also active freelance } \\
\text { interpreters }\end{array}$ & $7 / 10$ & $70 \%$ \\
\hline $\begin{array}{l}\text { Academics who acted as ST native speakers or } \\
\text { listeners during the examinations }\end{array}$ & $5 / 6$ & $83 \%$ \\
\hline Interpreting students & $5 / 10$ & $50 \%$ \\
\hline Total & $22 / 31$ & $71 \%$ \\
\hline
\end{tabular}

The total number of respondents was 22 ( 5 interpreting students, 5 academics, 7 freelance interpreters and 5 staff interpreters). The on-site survey method was chosen to enhance the cost-effectiveness of the study. The survey was conducted during an examination session in order to attain a high response 
rate. One advantage of administering questionnaires on the spot consisted in reducing the risk of misunderstanding and non-response (Berthier 2008: 2092010). It was speculated that the members of an examination board would be keen to participate because of their special interest in issues of norms and quality. The high overall response rate $(71 \%)$ supported this rationale. The students' response rate was lower. Indeed, some of them were particularly stressed or had failed the examination and preferred not to take part in the survey.

There were native and non-native French speakers among the 22 respondents. As the table suggests, all respondents mastered French quite well, whatever their native language.

Table 2. Subjects' mother tongue

\begin{tabular}{|l|c|c|l|}
\hline \multicolumn{1}{|c|}{ Nativeness } & $\mathbf{n}=$ & $\%$ & \multicolumn{1}{c|}{ Category Breakdown } \\
\hline $\begin{array}{l}\text { Native French } \\
\text { speakers }\end{array}$ & 17 & $77 \%$ & 5 students, 3 academics and 9 interpreters. \\
\hline $\begin{array}{l}\text { Non-native French } \\
\text { speakers }\end{array}$ & 5 & $23 \%$ & $\begin{array}{l}2 \text { academics (degree in French) and 3 interpreters } \\
\text { (French as a "B" language). }\end{array}$ \\
\hline
\end{tabular}

The interpreters' work experience (in years) is presented in the following table:

Table 3. Interpreters' work experience (in years)

\begin{tabular}{|l|c|c|l|}
\hline & Staff interpreters & Trainers who are freelance interpreters & Both \\
\hline Min. & 6 & 2 & 2 \\
\hline Median & 23 & 6 & 12 \\
\hline Mean & 30 & 9 & 14.46 \\
\hline Max. & 32 & 21 & 32 \\
\hline
\end{tabular}

\subsection{Questionnaire}

The questionnaire comprised 11 questions: 1 about the respondents' occupation, 1 about their work experience (in years) and 9 multiple-choice questions (MCQs). These MCQs presented realistic SI situations (STs) and a series of potential interpreter reactions (TTs). Eight MCQs involved an FTA and 1 was a common SI situation without any FTA. Each situation was based on cases from the literature (Diriker 2004, Monacelli 2009) or on instances personally witnessed in the booth. The original questionnaire in French is 
available online. ${ }^{1}$ The following table presents the gist of the SI situations and their corresponding FTAs:

Table 4: SI situations and their corresponding FTAs

\begin{tabular}{|c|c|c|}
\hline SI situation summary & Keyword & Face-threatening act \\
\hline 1. The speaker's speed of delivery is excessive. & Speed & $\begin{array}{l}\text { self- or other- } \\
\text { threatening, positive } \\
\text { face }\end{array}$ \\
\hline $\begin{array}{l}\text { 2. The speaker reads a text aloud with a very } \\
\text { monotonous intonation. }\end{array}$ & Monotony & $\begin{array}{l}\text { self- or other- } \\
\text { threatening, positive } \\
\text { face }\end{array}$ \\
\hline $\begin{array}{l}\text { 3. The speaker gets carried away and uses a rude } \\
\text { term. }\end{array}$ & Rudeness & $\begin{array}{l}\text { other-threatening, } \\
\text { positive face }\end{array}$ \\
\hline $\begin{array}{l}\text { 4. The speaker tells an anecdote and mentions } \\
\text { a household appliance whose name the } \\
\text { interpreter did not understand. }\end{array}$ & Anecdote & No FTA \\
\hline 5. The speaker says "billion" instead of "million". & Billion & $\begin{array}{l}\text { self-threatening, } \\
\text { positive face }\end{array}$ \\
\hline $\begin{array}{l}\text { 6. The speaker wrongly accuses the interpreters of } \\
\text { committing a mistake. }\end{array}$ & Accusation & $\begin{array}{l}\text { other-threatening, } \\
\text { positive face }\end{array}$ \\
\hline $\begin{array}{l}\text { 7. The chairperson makes an embarrassing aside } \\
\text { but forgets to switch off the microphone. }\end{array}$ & Aside & $\begin{array}{l}\text { self-threatening, } \\
\text { positive face }\end{array}$ \\
\hline $\begin{array}{l}\text { 8. The chairperson calls to order a speaker who is } \\
\text { monopolizing the floor. }\end{array}$ & Monopoly & $\begin{array}{l}\text { other-threatening, } \\
\text { negative face }\end{array}$ \\
\hline $\begin{array}{l}\text { 9. The chairperson warmly thanks the interpreters } \\
\text { at the end of the meeting. }\end{array}$ & Thanks & $\begin{array}{l}\text { self-threatening, } \\
\text { negative face }\end{array}$ \\
\hline
\end{tabular}

FTA types (self- or other-threatening; positive or negative face) follow Brown $\&$ Levinson's typology (1987: 65-68). All FTAs are considered from the point of view of the original speaker. For example, a rude or monotonous speaker threatens the hearers' positive face. If the chairperson thanks the interpreters, the chairperson is threatening his or her own negative face, because as he or she feels obliged to express gratitude, he or she is limiting his or her own freedom from imposition.

Each situation was followed by a series of potential reactions to the original speaker's FTAs. These reactions are also based on the literature and on

1. "Full_questionnaire_Lucentino.pdf" at <http: //hdl.handle.net/2013/UMONS-DI: oai: di.umons.ac.be: $13246>$ 
behaviour personally observed. They are located on a continuum between the honest spokesperson's role (accurate and faithful rendition, no distancing, use of the first person) and different kinds of interventions (distancing, replaying, shifts, etc.), which amount to face-saving strategies. For the situation rudeness, we invented a reaction that we have never observed (using a phrase which has the same rudeness in one's language). The reactions are summarized in the following table:

Table 5. Reactions to be selected in the questionnaire

\begin{tabular}{|c|c|c|c|}
\hline $\begin{array}{l}\text { SI situation } \\
\text { keyword }\end{array}$ & Reactions & Intervention & $\begin{array}{l}\text { Spokesperson } \\
\quad \text { (non- } \\
\text { intervention) }\end{array}$ \\
\hline Speed & $\begin{array}{l}\text { (a) Pushing the "slow down" button while } \\
\text { interpreting. } \\
\text { (b) Briefly interrupting the interpretation } \\
\text { to say that the speaker is reading a text } \\
\text { aloud which the interpreter has not } \\
\text { received. } \\
\text { (c) Briefly interrupting the interpretation } \\
\text { to ask the delegates to slow down the } \\
\text { speaker. } \\
\text { (d) When you are finished, adding that the } \\
\text { speaker spoke particularly fast. } \\
\text { (e) Interrupting the interpretation as in } \\
\text { (c), saying that it is impossible to } \\
\text { interpret under these circumstances } \\
\text { and switching off the microphone. } \\
\text { (f) As in (e), but instead of switching off } \\
\text { the microphone, threatening to do so. }\end{array}$ & (b) to (f) & (a) \\
\hline Monotony & $\begin{array}{l}\text { (a) Trying to make the intonation more } \\
\text { pleasant. } \\
\text { (b) Adopting the same intonation as the } \\
\text { speaker. }\end{array}$ & (a) & (b) \\
\hline Rudeness & $\begin{array}{l}\text { (a) Using a less derogative term. } \\
\text { (b) Suppressing the informal tone } \\
\text { and levelling up the register of the } \\
\text { interpretation. } \\
\text { (c) Using a phrase which has the same } \\
\text { rudeness in one's language. }\end{array}$ & (a), (b) & (c) \\
\hline Anecdote & $\begin{array}{l}\text { (a) Using a superordinate term ("a } \\
\text { household appliance"). } \\
\text { (b) Using a term which is probable given } \\
\text { the context ("a fridge"). }\end{array}$ & (b) & (a) \\
\hline
\end{tabular}




\begin{tabular}{|c|c|c|c|}
\hline Billion & $\begin{array}{l}\text { (a) Interpreting just what the speaker said. } \\
\text { (b) Correcting the mistake. } \\
\text { (c) As (a) but adding "says the speaker". }\end{array}$ & (b), (c) & (a) \\
\hline Accusation & $\begin{array}{l}\text { (a) Interpreting the accusation and adding } \\
\text { that the translation was actually } \\
\text { correct. } \\
\text { (b) Interpreting the accusation. } \\
\text { (c) Suppressing the accusation and } \\
\text { saying in the TT: "There is probably a } \\
\text { misunderstanding". } \\
\text { (d) As (b) but adding "says the speaker". }\end{array}$ & (a), (c), (d) & (b) \\
\hline Aside & $\begin{array}{l}\text { (a) Interpreting the aside. } \\
\text { (b) As (a) and adding that the chair's } \\
\text { comment was made off the } \\
\text { microphone. } \\
\text { (c) As (a) but making the aside less } \\
\text { embarrassing for the chair. } \\
\text { (d) A combination of (b) and (c). } \\
\text { (e) Ignoring the aside and commenting the } \\
\text { situation ("The chair is talking but the } \\
\text { microphone is switched off.") } \\
\text { (f) Ignoring the aside and switching off } \\
\text { the booth's microphone. }\end{array}$ & (b) to (f) & (a) \\
\hline Monopoly & $\begin{array}{l}\text { (a) Interpreting the speaker only and } \\
\text { commenting on the situation ("The } \\
\text { chair calls to order"). } \\
\text { (b) Interpreting the chair only. } \\
\text { (c) Interpreting the chair and the speaker } \\
\text { interrupting each other. } \\
\text { (d) As (c) but specifying for each turn who } \\
\text { is speaking. }\end{array}$ & (a), (b), (d) & (c) \\
\hline Thanks & $\begin{array}{l}\text { (a) Interpreting with some distance: "The } \\
\text { chair thanks the interpreters." } \\
\text { (b) Interpreting the thanks. }\end{array}$ & (a) & (b) \\
\hline
\end{tabular}

For each MCQ the respondents had to select the most appropriate reaction(s) and put them in order of priority. They were also given the possibility to propose a different reaction or add comments.

The questionnaire was pre-tested with a French-speaking academic and a French-speaking freelance conference interpreter. They were asked to answer the questions and to comment on any problem which might arise. This pretest helped to clarify the wording and layout of the questionnaire. 
Ten subjects answered and handed in the paper-and-pencil questionnaire during the breaks and at lunchtime during the examination session. Twelve respondents could not find the time to answer the questionnaire immediately. They sent their answers per e-mail a few days after the examination session.

\subsection{Data analysis}

The answers have been coded in a table using Microsoft Excel. The first question aimed to elicit the variable category with 4 modalities: staff interpreter, trainer who is a freelance interpreter, academic or student. The 9 MCQs provided the data for the second variable (appropriate reactions) with two modalities: spokesperson or intervention.

In this study the spokesperson's role corresponds to the absence of intervention in the TT. Our definition of the spokesperson's role corresponds to that of an interpreter who speaks in the first person in the name of the speaker, does not voluntarily add or omit anything in the TT and sticks as much as possible to the form and to the meaning of the ST. For example, for the rudeness situation, using a phrase which has the same rudeness in the target language as in the ST has been considered to be a spokesperson's reaction.

Conversely, a TT which contains one or more shifts (distancing, additions, omissions, comments, tone or register enhancement, etc.) has been considered to contain interventions. For example, in the 'rudeness' situation, using a less derogative term than in the ST has been considered to be an intervention. These interventions amount to face-saving strategies.

The respondents had also been asked to rank the reactions from the most to the least appropriate. However, some respondents selected one reaction only. Others selected two reactions but did not give an order of priority. Consequently, the rankings were discarded from the analysis in order to keep results consistent. This means that when there was a ranking, only the reaction(s) which had ranked first have been taken into account. Some respondents ranked first several reactions. In such cases, they were all taken into account. The data have been processed using Microsoft Excel and IBM SPSS Statistics. The figures have been created using OpenOffice Draw.

\section{Results}

The stacked bar chart below shows the frequency distribution on all the categories divided up by the spokesperson modality (bar on the left) or the intervention modality (bar on the right). 


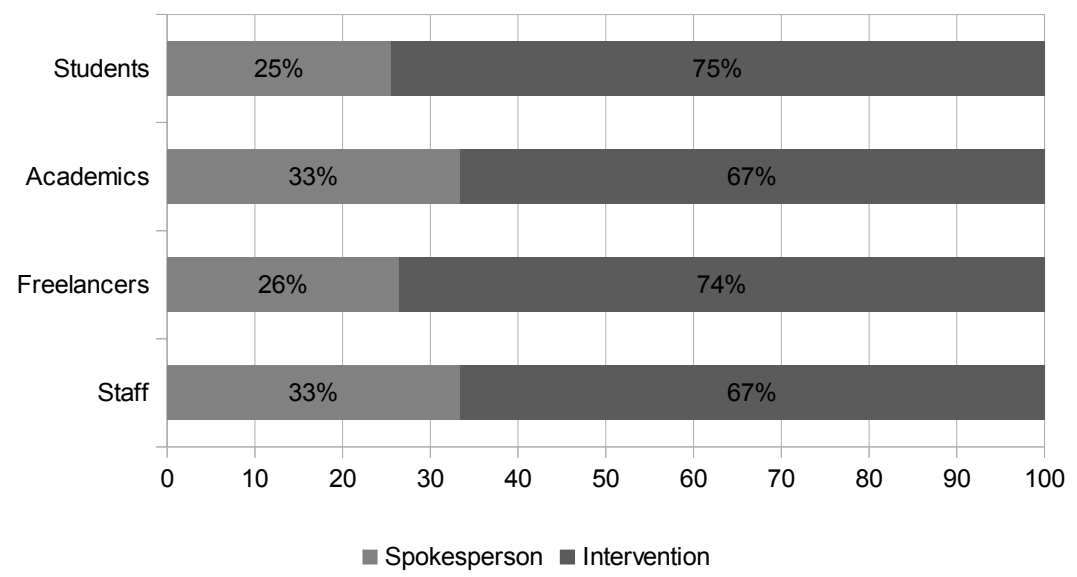

Fig. 1. Frequency distribution on all categories divided up by reaction types.

The differences between the categories are minimal. There seems to be an overall tendency in favour of interventions, regardless of the category. Indeed, $71 \%(\mathrm{n}=215)^{2}$ of the reactions selected by the respondents correspond to the intervention modality.

The results of a Kruskal-Wallis test were not significant for both reaction types: intervention $(\mathrm{p}=0.395)$ and spokesperson $(\mathrm{p}=0.782)$; the mean ranks of reaction types do not differ significantly within the four categories. This means that our hypothesis could not be corroborated. The results will now be discussed regardless of the respondents' category.

The stacked bar chart below gives a more detailed view of the results. It shows the frequency distribution on all the questions, divided up by the spokesperson or intervention reaction, without regard for the respondents' category.

When the ST speaker makes an aside without switching off the microphone $(\mathrm{n}=22)$, when he says billion instead of million $(\mathrm{n}=24)$ or when he is particularly monotonous $(\mathrm{n}=22)$, the 'intervention' modality accounts for $100 \%$ of the answers. When a rude term is uttered, an intervention is considered to be the best reaction in $86 \%(n=22)$ of cases.

Conversely, the spokesperson modality is considered to be the best reaction in $75 \%(n=24)$ of cases where the delivery of the speaker is too fast. In

2. $\mathrm{n}=$ total number of reactions selected by the 22 respondents, with an average of 9,77 reactions selected per questionnaire $(9,77 * 22=215)$. 


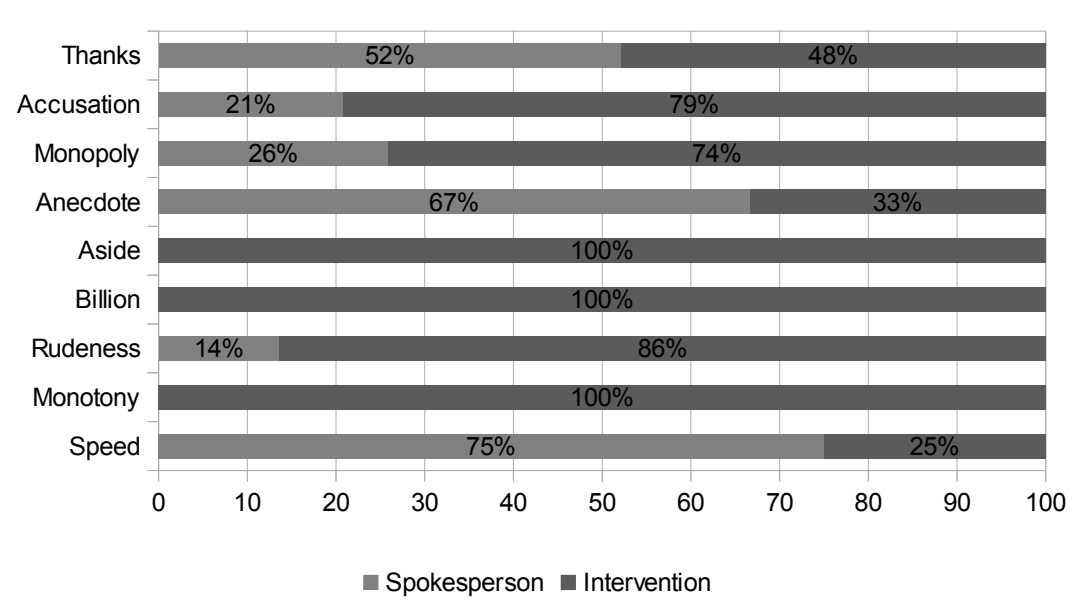

Fig. 2: Frequency distribution on all questions divided up by reaction types.

$67 \%(n=27)$ of cases, the respondents considered that it is appropriate to stick to the spokesperson's role when an anecdote in the ST has not been completely understood. In the case where the chairman thanks the interpreters, the answers are almost equally divided $(n=23)$ between the two modalities.

\section{Discussion}

We could not corroborate the hypothesis that there is a link between the status (i.e. the category) of the respondents and the acceptance of deviations from the honest spokesperson's role in SI instances containing an FTA. In other words, the fact that a respondent is an interpreter, an academic or a student does not significantly influence his or her favourite reactions to an FTA.

One explanation could be that for reactions to FTAs, the interpreters' assessment norms are not specific to the profession. This would imply that the assessment norms of politeness strategies are not acquired through socialization in the interpreting field. Indeed, FTAs occur in all spoken interactions. As a result, the assessment of reactions to FTAs might pertain to an overarching set of norms which is common to the speakers of a given cultural group, regardless of their status. A different explanation could be that the assessment norms do not significantly differ because all the subjects have acquired these norms through a common process of socialization. Indeed, all the examiners had previous experience in the assessment of SI in training institutions. The students had had a regular contact with their trainers for the previous two years. Consequently, they are likely to have inherited their 
trainers' assessment norms. This would explain why the overarching group of examination participants has relatively homogenous assessment norms.

To determine which explanation is the right one, one could conduct a larger-scale survey and compare the answers of a sample of interpreters within a given national or international organization with those subjects who know about SI but have had no or little experience in its assessment. Candidates for such a study could be for instance delegates in a multilingual meeting in the same organization.

For the time being, the results already indicate an interesting trend. Indeed, the high overall percentage of answers in favour of an intervention indicates a strong tendency for the respondents to consider the interpreters' interventions to be appropriate when the speaker's, hearers' or interpreters' face is at stake.

For a large majority of respondents, it is appropriate that interpreters intervene in the TT in the following cases: the ST speaker makes an aside without switching off the microphone; the ST speaker says billion instead of million; the ST speaker's delivery is particularly monotonous; the ST speaker utters a rude term. For the first three reactions, a remarkable 100\% of respondents are in favour of interventions. Interpreters transform a monotonous ST into a livelier TT; they play down rude terms; they ignore asides and they replay slips of the tongue by adding 'says the speaker'. To a slightly lesser extent, interventions are considered to be appropriate in the following cases: an ST speaker wrongly accuses the interpreters of a mistake; there is a conflict between the chair and a speaker who monopolizes the floor. All these instances contain FTAs.

The other results are not so clear-cut. One half of the respondents reckon that it is appropriate to add distancing and moderation to the chair's thanks (e.g. by saying: The chair thanks the interpreters), whereas the other half supports a neutral interpretation (e.g. by saying: I would like to thank the interpreters for their wonderful job). The diversity of the respondents' working environments could be an explanation. But since interpreters, academics and students alike are divided on this question, a more convincing explanation could be that thanks are not face-threatening, but face-flattering acts (FFAs, Kerbrat-Orecchioni 1996: 55-60). These FFAs might call for a different set of norms, which remain to be explored.

For the majority of respondents, excessive speed calls for a spokesperson's reaction: pushing on the slow down button. This would make of excessive speed a very common FTA in SI, which calls for a spokesperson's role. However, the slow down button is not always available. And even if it is 
available, its effects are never guaranteed. Sooner or later, interpreters faced with breakneck speed in the ST thus probably have to intervene in the TT. One possibility is to explicitly inform the delegates that the speaker is too fast. Interestingly enough, two senior interpreters discard such an explicit approach and allude to an implicit intervention in line with the condensation norm (Shlesinger 1999). In this regard, the following comment of a respondent is explicitly relevant:

the delegates can ask the speaker to slow down if they want quality interpreting. Pushing the ["slow down"] button has no effect on the speaker, even if the chair intervenes. Interrupting [the interpretation] to say that the speaker is racing through a text ANNOYS THE DELEGATIONS. If you say at the end that the speaker spoke too fast, it's TOO LATE! NEVER switch off the mike. Threatening to switch off the mike is like penalizing the delegates. It is better to provide them with a summary. (Original capitals, my translation) ${ }^{3}$

The remark comes from a senior staff interpreter. Another senior interpreter made a similar comment. These comments are in line with Straniero Sergio's observation that when interpreting under adverse conditions "the norm [...] is the rendition of the essentials" (2003: 170, original emphasis). In future questionnaires, the question about excessive speed might turn out to be more valid if the proposed reactions included making a summary and excluded the slow down button option.

The respondents did not support interventions in the TT when the interpreter does not understand an anecdote told by the speaker. The anecdote is about a household appliance which is the epitome of longevity. The interpreter has understood the comparison but not the name of the appliance. In the TT, the intervention consists in inventing a probable example (e.g. a fridge), whereas the spokesperson only says a household appliance. The spokesperson was chosen more frequently $(67 \%, \mathrm{n}=27)$. This is in line with our explanatory framework. Indeed, we did not expect a non-face-threatening situation like the anecdote to trigger legitimate interventions in the TT. This result might indicate that the respondents are not inherently interventionists and that the FTAs have really influenced their assessment.

3. "les délégués peuvent demander à l'orateur de ralentir s'ils veulent une interprétation de qualité. Appuyer sur le bouton n'a aucun effet sur l'orateur, même si le président dit quelque chose. Interrompre pour dire que l'orateur lit vite un texte ÉNERVE LES DÉLÉGATIONS. Dire à la fin qu'il a parlé trop vite, c'est TROP TARD ! NE JAMAIS couper le micro. Menacer de couper le micro revient à pénaliser les délégués. Mieux vaut leur faire un résumé." 
To sum up, no significant link between the category and the assessment of reactions to FTAs was found. There is a strong tendency that FTAs call for interventions which are largely considered to be legitimate by respondents familiar with SI assessment. This consensus could be characterized as being the expression of underlying norms in the assessment of SI. These norms are consistent with previous findings about translational norms in SI (e.g. Monacelli 2009). They could thus reflect an overall attitude towards SI. However, SI is a very broad social context for the study of norms. Surveys on norms and politeness strategies ought to focus on more narrowly-defined interpreting settings.

The results discussed here apply only to a limited group of subjects $(n=22)$. Five subjects are non-native speakers. Since politeness strategies are culture-bound, the mother tongue of the respondents might have influenced their responses.

\section{Conclusion}

Previous studies have suggested that interpreters could subordinate all their decisions to "the preservation of their professional face" (Monacelli 2009: 53). FTAs in the ST seem to trigger interventions in the TT such as distancing or shift in the speaker's position (Diriker 2004, Monacelli 2009). These shifts challenge the universality of the interpreter's role as a faithful and honest spokesperson who always speaks in the first person in the name of the ST speaker.

In this paper we have explored assessment norms of interpreting in instances involving an FTA. We have hypothesized that assessment norms would be linked to the respondents' status. Professional interpreters, academics and interpreting students answered a questionnaire which contained realistic SI situations involving an FTA.

No significant inter-group difference was found. A large majority of the respondents considered that departures from the honest spokesperson's role were legitimate in almost all instances with FTAs.

Our hypothesis could not be corroborated. This leads to two new hypotheses. First, the assessment of reactions to FTAs pertains to an overarching set of norms, which is not bound by the respondents' status. Second, examination participants acquire a common sense of assessment norms in interpreting through the training and examination process. Surveying subjects who are less familiar with interpreting assessment might help to corroborate or disprove these two hypotheses. 
Future empirical research on assessment norms in SI could refine the method presented in this paper. Clarifying the instructions about how to prioritize the selected reactions, integrating the condensation norm among the potential reactions to FTAs and better defining the common working environment, the linguistic community and the assessment experience of the subjects could enhance the quality of the results.

In conclusion, this study provides good reasons to further explore the link between assessment norms, translational norms in SI and politeness strategies. Translational norms are implemented during the interpreting process and assessment norms guide the assessment of interpreting performance. Consequently, assessment norms are crucial and ubiquitous variables in research on SI quality. A better knowledge of these norms and hence of quality is relevant not only for researchers but also for trainers and practitioners interested in a critical approach of quality assessment in SI.

\section{References}

ARCHER, Dawn; Jonathan Culpeper \& Matthew Davies. (2008) "Pragmatic annotation." In: Lüdeling, Anke \& Merja Kytö (eds.) 2008. Corpus Linguistics: An International Handbook, Vol. I. Berlin \& New York: Walter de Gruyter, pp. 613-642.

Bendazzoli, Claudio \& Annalisa Sandrelli. (2009) "Corpus-based interpreting studies: Early work and future prospects." Tradumàtica 7 . Electronic version: <http://webs2002.uab.es/tradumatica/revista/num7/articles/08/08art.htm>

BERTHIER, Nicole. (2008) Les Techniques d'enquête en sciences sociales. Méthode et Exercices corrigés. Paris: Armand Colin.

Brown, Penelope \& Stephen Levinson. (1987) Politeness: Some Universals in Language Usage. Cambridge: Cambridge University Press.

DIRIKER, Ebru. (2004) De-/Re-Contextualizing Conference Interpreting: Interpreters in the Ivory Tower? Amsterdam \& Philadelphia: John Benjamins.

GOFFMAN, Erving. (1967) Interaction Ritual: Essays on face-to-face behaviour. New York: Doubleday.

Goffman, Erving. (1981) Forms of talk. Philadelphia: University of Pennsylvania Press.

HARRIS, Brian. (1990) "Norms in interpretation." Target 2:1, pp. 115-119.

Kerbrat-Orecchioni, Catherine. (1996) La Conversation. Paris: Editions du Seuil.

MonaCelli, Claudia. (2009) Self-Preservation in Simultaneous Interpreting: Surviving the Role. Amsterdam \& Philadelphia: John Benjamins.

PÖCHHACKER, Franz \& Miriam Shlesinger (eds.) (2002) The Interpreting Studies Reader. London \& New York: Routledge. 
SHLESINGER, Miriam. (1999) "Norms, strategies and constraints: how do we tell them apart?" In: Álvarez Lugrís, Alberto \& Anxo Fernández Ocampo (eds.) 1999. Anovar anosar, estudios de traducción e interpretación. Vigo: Servicio de Publicacións da Universidade de Vigo, pp. 65-77.

Straniero SERGIO, Francesco. (2003) "Norms and quality in media interpreting: the case of formula one press-conference." The Interpreters' Newsletter 12, pp. 135-174.

Straniero Sergio, Francesco \& Caterina Falbo. (2012) Breaking Ground in Corpus-Based Interpreting Studies. Bern: Peter Lang.

TOURY, Gideon. (1980) In Search of a Theory of Translation. Tel Aviv: Porter Institute for Poetics and Semiotics, Tel Aviv University.

TOURY, Gideon. (1995) Descriptive Translation Studies and beyond. Amsterdam \& Philadelphia: John Benjamins.

TouRY, Gideon. (1998) "A Handful of Paragraphs on 'Translation' and 'Norms'." In: Schäffner, Christina (ed.) 1998. Translation and Norms. Clevedon: Multilingual Matters, pp. 10-32. Electronic version: <http: //www.tau.ac.il/ toury/works/GT-Handful_Norms.htm>

VV.AA. (AIIC - International Association of Conference Interpreters). (1990/2004) Practical Guidefor Professional Conference Interpreters. Electronic version: <http: //aiic.net/page/628/practical-guide-for-professional-conference-interpreters/ lang/1\#5> 


\section{BIONOTE / NOTA BIOGRÁFICA}

CÉDRIC LENGLET is a conference interpreter and a doctoral candidate at the University of Mons (FTI-EII), where he obtained a MA in conference interpreting in 2010. He currently works as a research assistant at the Department for specialized translation and terminology of that university, under the supervision of Dr. Christine Michaux. His PhD project is an experimental research dealing with the impact of target speech prosody on the users' comprehension and assessment of simultaneous interpreting. His research interests are prosody, quality and norms in simultaneous interpreting and note-taking in consecutive interpreting. His working languages as a conference interpreter are French, English, German and Spanish.

CÉDRIC LENGLET es intérprete de conferencia y se encuentra realizando su doctorado en la Universidad de Mons (FTI-EII), por la que obtuvo su título de máster en interpretación de conferencias en 2010. Actualmente trabaja en calidad de doctorando e investigador para el Servicio de Traducción Especializada y Terminología de dicha universidad, bajo la supervisión de Christine Michaux. Su tesis doctoral es una investigación experimental que versa sobre el impacto de los rasgos prosódicos del discurso meta sobre la comprensión y la evaluación de la interpretación simultánea por parte de los usuarios. Sus líneas de investigación preferentes son la prosodia, la calidad y las normas en la interpretación simultánea, así como la toma de notas en consecutiva. Como intérprete, sus lenguas de trabajo son el francés, el inglés, el alemán y el español. 